\title{
Andrzej Walicki
}

Andrzej Walicki, the Polish historian of ideas, died in Warsaw on August 20, 2020. At his death, his publications numbered more than four hundred entries, including twenty-five single-authored books. This record of accomplishment made him one of the twentieth century's great intellectual historians. In recognition, he received the 1998 International Balzan Prize for History. In 2005, Polish President Aleksander Kwaśniewski awarded him the Grand Cross of the Order of Polonia Restituta.

Andrzej Stanisław Walicki was born in Warsaw on May 15, 1930. His father, Michał Walicki (1904-66) was a professor of art history. His mother, Anna Chmielewska (1905-81), was an adjunct professor of education, an innovator in her field of social pedagogy. As a boy Walicki witnessed the Nazi occupation of Warsaw with all its cruelty. His father joined the Polish Home Army as an intelligence officer. Later, under Polish Stalinism, Michał Walicki was imprisoned for five years as an "enemy of the people.” Poland's fate provoked Andrzej's curiosity about history-the history of the Polish nation, the history of Marxism, and the idea of the "end of history."

Walicki completed high school in Łódź and began undergraduate studies at the city's new university in 1949. He enrolled in the Russian Studies Department, the only one open to him at the time, because he came from the wrong "social and family background." Although his family had long ties to Russia and its culture, the most important pro-Russian influence on him was his childhood mentor, Sergius Hessen (1887-1950), an émigré Russian philosopher who had moved from Prague to Warsaw in 1935 to take up the chair of philosophy of education at the Free University of Poland. After the war, both Walicki and Hessen wound up in Łódź, Walicki as a student, and Hessen as a professor at the new university. Decades later, Walicki dedicated the last chapter of his Legal Philosophies of Russian Liberalism (1987) to Hessen, and still later (in 1999), he produced a Russian edition of his works.

In 1950 Walicki transferred to the University of Warsaw, where he read broadly in Russian literature and thought, as well as in the history of philosophy. He remarked that his education consisted of "reading polnye sobraniia sochinenii from cover to cover." However, the Warsaw authorities accused him of the crime of "individualism," and mounted denunciations against him. Fortunately, during the post-Stalin thaw, all the doors previously closed to him seemed to re-open. In 1955-56 he launched the research program that he pursued for the rest of his life: the study of the history of Russian and Polish thought, the study of Marxist thought and practice, and the "translation" of nineteenth-century Russian thought to the (ignorant) west. He earned his MA and PhD degrees from Warsaw University in 1953 and 1957, respectively. In 1958 he became an adjunct (assistant professor) in the history of social thought at Warsaw University. Two years later he moved to the Institute of Philosophy and Sociology of the Polish Academy of Sciences, where in 1972 he was promoted to full professor. Together with Leszek Kołakowski and Bronisław Baczko, he became a member of the so-called "Warsaw school" in the history of ideas.

In his first book, Osobowość a historia: Studia z dziejów literatury i myśli rosyjskiej (Personality and History: Studies in the History of Russian Literature and Thought, 1959), Walicki explored the conflict between ethical freedom and alleged historical necessity, showing how leading Russian thinkers and writers opposed the idea of historical determinism in the name of human freedom and moral responsibility. In 1960 he received a Ford Foundation fellowship for study in Great Britain and the 
United States. At the beginning of his trip he met Isaiah Berlin at All Souls College, University of Oxford. Their common approach to Russian thinkers such as Vissarion Belinskii and Alexander Herzen led to an intellectual friendship that lasted until Berlin's death in 1997. In the 1966-67 academic year and in autumn 1973, visiting fellowships at All Souls College facilitated the publication of Walicki's first two books in English: The Controversy over Capitalism: Studies in the Social Philosophy of the Russian Populists (1969) and The Slavophile Controversy: History of a Conservative Utopia in Nineteenth-Century Russian Thought (1975). Similarly, a visiting professorship in history at Stanford University in 1976 led to the English edition of A History of Russian Thought from the Enlightenment to Marxism $(1979,1980)$.

The Slavophile Controversy powerfully exemplified Walicki's approach to the history of ideas: the empathetic reconstruction of a worldview (in this case Slavophile conservative romanticism), with close attention both to the immediate historicalintellectual context and to philosophical problems transcending that context. What Walicki valued most in Russian thought was its defense of the human being against dehumanizing or depersonalizing ideologies, whether that defense took the form of the "autonomous individual" (in the case of the Westernizers) or the "integral person" (in the case of the Slavophiles). Appreciation of secular and religious modes of grounding human dignity, which owed very much to his teacher Sergius Hessen, was at the heart of Walicki's commitment to "value pluralism."

Walicki believed that human beings can reach their full potential only in harmonious communities. This helps explain his interest in Polish romantic nationalism and in Slavophilism. He sharply distinguished between conceptions of national identity that embody universal human values and those "integral nationalisms" which divide one group from the rest of humanity.

Two weeks before the imposition of martial law in December 1981, Walicki left Poland for a position as senior research fellow in the history of ideas at the Australian National University in Canberra. The main product of his five years in Canberra, Legal Philosophies of Russian Liberalism, showcased six philosophers, who defended the human person as an end-in-itself and who saw the rule of law as crucial to the achievement of human dignity. The book demonstrated the link between religious assumptions about innate human dignity and the realization of human rights, in theorists such as Boris Chicherin, Vladimir Solov'ev, and Pavel Novgorodtsev.

From late 1986 to 1999, Walicki taught graduate students at the University of Notre Dame. He proved himself both a demanding and an encouraging mentor, one who helped his students find the right research topics for their particular dispositions of soul and mind. He was an extraordinarily generous colleague, sharing his work and constructive remarks on others' manuscripts, as well as his good cheer. At dinners, he was equally happy to sing Polish and Russian songs, or to recite Russian poetry, or to play chess with colleagues' children. Walicki's major book at Notre Dame, Marxism and the Leap to the Kingdom of Freedom: The Rise and Fall of the Communist Utopia (1995), was awarded the Wayne S. Vucinich Prize by the American Association for the Advancement of Slavic Studies. Next to Kołakowski's Main Currents of Marxism (English translation 1978), it was the most erudite and authoritative treatment of Marxism's political history from its inception to the end of Stalinism.

Walicki became professor emeritus in 1999. Before returning to Poland in 2006, he finished a greatly expanded edition of his History of Russian Thought. It was published in Polish in 2005 and ten years later in English, as The Flow of Ideas: Russian Thought from the Enlightenment to the Religious-Philosophical Renaissance. For his students and admirers, Andrzej Walicki built a bridge between Russia and the west, a bridge that beckons others to cross. 
For more biographical information, see Andrzej Walicki, Encounters with Isaiah Berlin: Story of an Intellectual Friendship (Frankfurt am Main, 2011), and Gary M. Hamburg, "Closed Societies, Open Minds: Andrzej Walicki, Isaiah Berlin and the Writing of Russian History during the Cold War," Dialogue and Universalism (Institute of Philosophy, Warsaw University) 16/1-2 (2006): 73-79.

\author{
G. M. HAMBURG \\ Claremont McKenna College \\ RANDAll A. POOLE \\ College of St. Scholastica
}

\title{
Stephen F. Cohen
}

Wherever Steve Cohen (1938-2020) appeared-on radio and television, in The Nation magazine edited and published by his wife Katrina vanden Heuvel, or in his biography of Nikolai Bukharin-he was met with strong feelings, criticism, and praise. An esteemed colleague to many, a baleful apologist for Russian leaders to others, and a comrade to me personally, Steve was a unique presence in the Sovietological profession. A relentless critic of the historiography of western analysts of the Soviet Union, an extraordinarily confident public intellectual, and a controversial critic of the responsibility of intellectuals in the public arena, he ruffled the feathers of those scholarly birds that flocked together. Steve boldly straddled the fields of history and political science in the decades before political science turned inward to a narrower concentration on rational choice and statistical explanations. Curiously, he could rail at the facile anti-Russian and anti-Soviet biases that often marred the study of the USSR and simultaneously maintain a cordial relationship with dedicated anticommunists like Robert Conquest, friendships with persecuted dissidents within the Soviet Union, and an enviable connection to Mikhail Gorbachev, who admired his work even if he did not completely agree with it. Ultimately, Cohen was the major dissident within Soviet studies, the object of bitter polemics and accusations that at one low point divided the major scholarly association that studied the subjects to which he had dedicated his life.

Born in Indianapolis, educated in Kentucky and Florida, Stephen Frand Cohen graduated from Indiana University, where he studied with Sovietologist Robert C. Tucker, and went on to receive his PhD from Columbia University in 1969. His dissertation, which became his first and major historical work, Bukharin and the Bolshevik Revolution: A Political Biography, 1888-1938, was published by the distinguished house of Alfred A. Knopf in 1973. In a review by the eminent economic historian Alec Nove, the book was hailed as "a great achievement," "the best book to be published on the USSR for many years.” A monumental work, beautifully written with a deep empathy for the tragic fate of its protagonist, the book developed the argument that had been pioneered by Moshe Lewin and Tucker that Stalinism had to be distinguished from original Bolshevism and that alternative possibilities for Soviet development had existed before the ruthless rise of Iosif Stalin. Western historiography on the Soviet Union divided between those who saw an unbreakable continuity from Vladimir Lenin to Stalinism and those who argued, as Lev Trotskii claimed, that "a river of blood" separated the revolution and Bolshevism from Stalin's autocracy. Cohen shifted the narrative about the New Economic Policy of the 1920s that centered on the power struggle between Trotskii and Stalin to focusing on the attractive figure 
of Bukharin, who in his telling provided a more humane road to socialism than the one that unraveled the original Bolshevik vision.

The argument of a break between Bolshevism and Stalinism had not only the advantage of explaining the subsequent murders of the former Leninist leadership in the party but also of opening up Soviet historiography to new and interesting questions. Cohen's discussion remained largely on the level of description of the differences between two socio-political orders and did not provide a full analysis of the social transformation of one into the other. But he rejected the bureaucracy-asruling-class or caste arguments associated with Trotskii and his followers, claiming instead that in Stalin's personal despotism the bureaucracy did not ultimately rule. In Cohen's view, Stalinism was an extraordinarily excessive and brutal political response to a social crisis that had been created by Stalin and was neither inevitable nor the only outcome of Bolshevism. To explain full-blown Stalinism, Cohen nodded toward Tucker and the elusive notion of Russia's political culture. Traditional values were resurrected in the 1930s along with Russian nationalism, and the gargantuan cult of the leader was at one and the same time an expression of genuine popular support and religious traditions. Stalinism in its inception had been a catastrophic revolutionary upheaval, directed by the state against society; in its full realization it metamorphosed into a rigid, conservative, traditionalist system.

Cohen followed Tucker to Princeton, where he taught for thirty years before decamping to New York University. As a charismatic teacher with classes overflowing with admiring students, he published a series of provocative books, beginning most forcefully with his review of western writing on the USSR, Rethinking the Soviet Experience: Politics and History Since 1917 (New York and Oxford: Oxford University Press, 1985), and a collection of articles from The Nation on current east-west politics, Sovieticus: American Perceptions and Soviet Realities (New York: W. W. Norton, 1985). By the 1980s he had become one of the most visible public intellectuals commenting on Soviet politics, a commentator on CBS, and through a fortuitous turn of fate his theses about Bukharin took on a contemporary relevance with the reforms of Gorbachev. His master work was translated and published in the Soviet Union, and NEP became a legitimized historical inspiration for a new direction for Soviet economics and politics. On May Day 1989, as a guest of the General Secretary of the Communist Party of the Soviet Union, he and Katrina watched the festivities and military parade from the Lenin Mausoleum.

A long-time believer in the possibility of meaningful reform of the Soviet Union, Cohen's more détentist, less condemnatory attitudes toward the USSR found a following among Western pundits and scholars. His views were close to those of the socalled "revisionists" in Soviet history, though he was fiercely critical of anyone who avoided the required condemnation of the excesses of Stalinism, most particularly the Great Terror. He and Tucker had years earlier edited and reissued the transcript of the 1938 show trial that condemned Bukharin-The Great Purge Trial (New York: Grosset \& Dunlap, 1965) - the same case immortalized in Arthur Koestler's Darkness at Noon. Although he would frequently be attacked as an apologist for Gorbachev or Vladimir Putin, Cohen remained a severe opponent of authoritarianism and its myriad brutalities and close to the recurring dissident movements in the USSR. In a series of works-An End to Silence: Uncensored Opinion in the Soviet Union (New York: W. W. Norton, 1982); with Katrina vanden Heuvel, Voices of Glasnost: Interviews with Gorbachev's Reformers (New York: W. W. Norton, 1989); and The Victims Return: Survivors of the Gulag After Stalin (Exeter, NH: Publishing Works, 2010)-he repeatedly returned to those who had dissented and suffered for it. He befriended Anna Larina, the widow of Bukharin, who had "sat," as they say in Russian, in prison and 
labor camps for two decades. After her release he discovered the last letter that her husband had written to her in the archives and returned it to her.

The ultimate failure of Soviet reform to preserve the Union and move the country to the social democracy desired by Gorbachev disappointed, even discouraged, many on the Left who hoped for an alternative between Soviet-style "socialism" and the neoliberal capitalism then hegemonic in many western states. Cohen castigated the self-styled "democrats" like Boris Yeltsin who had abandoned and defeated Gorbachev and in articles and books he inveighed against American and European policies toward the new Russian Federation. In Failed Crusade: America and the Tragedy of Post-Communist Russia (New York: W. W. Norton, 2000); Soviet Fates and Lost Alternatives: From Stalinism to the New Cold War (New York: Columbia University Press, 2009, 2011); Why Cold War Again: How America Lost Post-Soviet Russia (London: I. B. Tauris, 2016); and War with Russia: From Putin \& Ukraine to Trump \& Russiagate (New York: Hotbooks, 2019), he emerged once again as a dissident voice. His critical position on American journalists and pundits appeared shrill to those enthusiastic about the post-Soviet transition to democracy and capitalism. He laid much of the blame for international conflict on the United States, which given its enormous economic and military power was squandering the best opportunity in modern times to create a more effective international environment. As Yeltsin ceded power to Vladimir Putin, and free-wheeling democracy and the power of Russian oligarchs descended into a new authoritarianism and increased economic power of the state, opinion in the West turned against Russia and its rulers. Cohen once again refused to give in to the prevailing trends and attempted to explain Russia's actions as rational defenses of its national interest. His prevailing vision was that East-West cooperation rather than confrontation was essential for peace, prosperity, progress, and even survival. Just as he had opposed earlier the stark contrasts and that maintained the Cold War, in his last years he warned about the costs of a new Cold War. Like the deans of American Realpolitik, George F. Kennan and Henry Kissinger, strange bedfellows for a man of the Left like Cohen, he warned that there would be serious consequences of NATO expansion and the isolation of Russia. The first major evidence for his prediction came with the Georgian-Russian War of 2008.

When Ukrainians went into the streets in 2013-2014 to challenge and change their government, the consequent violence, fall of the regime, and annexation of Crimea by Russia resulted in the most bitter confrontation of Europe, the United States, and Russia since the disintegration of the USSR. The east-west struggle over the fate and allegiance of Ukraine divided not only public opinion about Russia but the scholarly community as well. Cohen's critics labelled him "Putin's American toady" and accused him of recycling Russian political propaganda. He retorted that he saw Putin as a rational actor who had stabilized Russia and acted in the interest of his country. The fierce opposition to his attempt to complicate the reductive readings of Russian policies led to the principal scholarly organization in Russian and east European studies, the Association for Slavic, East European, and Eurasian Studies, initially to reject a large donation from Ms. vanden Heuvel to honor Cohen and his mentor Tucker with the funding of a dissertation fellowship. Letters flew back and forth before the dispute was amicably settled. But damage had been done. Even in the post-Cold War world younger scholars might take note that dissent has its price.

Steve Cohen liked to quote the humorist Will Rogers' famous quip about Russia: "Russia is a country that no matter what you say about it, it's true. Even if it's a lie, it's true. If it's about Russia." Governments and their organic intellectuals, nationalists and defenders of one nation against another have their own interests in painting their international rivals in dark colors. Scholars have the more difficult task of critical examination of accepted or unquestioned assumptions about the Other, the 
foreign, the obscure, and the complex. In the fraught political climate of the Cold War and its aftermath, trying to explain Russia as Cohen tried to do has been seen as rationalizing (in both senses of the word) Russian behavior. Cohen's boldness sometimes lacked subtlety and nuance; his polemical style occasionally was accompanied by exaggeration. But what he wrote or broadcast was always based on his honest research, clear-headed analysis, and a heartfelt concern for accurate understanding. He was motivated by a genuine passion to get the story right. Like many in the field of Slavic and east European studies, Steve Cohen was pained by the facile distortions and the hoary myths that clung to popular perceptions of Russia and the Soviet Union, Marxism, socialism more broadly, and the intricacies of international relations.

Unless he was being ironic or sardonic, Shakespeare got it wrong when Marc Antony implored his countrymen to lend him their ears and claimed that he had come "to bury Caesar, not to praise him." "The evil that men do lives after them. The good is oft interred with their bones.” Really? Isn't it usually, at least for famous figures, just the opposite? So, let it not be with Steve Cohen. He had his share of praise and calumny during his productive life, but in a time when judgment "art fled to brutish beasts" and "men have lost their reason," Steve's courageous example of challenging the prevailing winds of opinion remain an inspiring example of what critical scholarship ought to be.

RONALD GRIGOR SUNY The University of Michigan The University of Chicago, Emeritus

\section{Keith Hitchins}

Six months short of his ninetieth birthday, Professor Keith Hitchins (1931-2020), the venerated doyen of Romanian and east European studies, passed away on November 1,2020 . The field has lost a giant but his august presence as a prodigious scholar, inspired teacher, and exemplary human being has left a shining legacy. Keith Arnold Hitchins was born on April 2, 1931 in Schenectady, New York and will be resting next to his parents, Henry Arnold Hitchins and Lillian Mary Turrian, at Woestina Cemetery in Schenectady. After graduating from Union College in Schenectady in 1952, Hitchins continued his graduate studies at Harvard University with an MA in 1953 and a PhD in 1964. Specializing in east European and Soviet studies, he studied Romanian language and literature in Paris in 1957-58 and at the Universities of Bucharest and Cluj in 1960-62. He started his teaching career as an instructor and then assistant professor of history at Wake Forest University, Winston-Salem, North Carolina from 1958 until 1965. For two years he was Assistant Professor of History at Rice University, Houston. In 1967, he accepted a tenured position at the Department of History of the University Illinois, Urbana-Champaign, to teach east European history. He was a beloved professor, teaching generations of students for fifty-two years, before going into retirement in 2019.

A scholar of tremendous range and vision, Professor Keith Hitchins spanned the area from eastern Europe to Central Asia. There is no doubt, however, that his heart and tremendous achievement lay in the history of Romania. Described as the American Nicolae Iorga, the legendary Romanian historian, Keith was celebrated and beloved not only for his impeccable and balanced work but for his beautiful, accentless Romanian. His first book, The Rumanian National Movement in Transylvania, 1780-1849 (Harvard, 1969), is over a half century old but has remained unsurpassed 
as the definitive study of the evolution of the Romanian national movement. Already in this work, Hitchins exhibited his proverbial sense of tact and balance in an issue that has been strongly contested. This was followed by Orthodoxy and Nationality: Andreiu Şaguna and the Rumanians of Transylvania, 1846-1873 (Harvard, 1977), The Idea of Nation: The Romanians of Transylvania, 1692-1849 (Editura ȘtințificăBucharest, 1985), and his magisterial two volumes Rumania: 1866-1947 (Clarendon Press, Oxford, 1994) and The Romanians 1774-1866 (Clarendon Press, Oxford, 1996).

Keith was a real scholar and he served as the role model for several generations. One litmus tests for a good historian is the footnotes. You start with them and it is clear not only how solid the edifice is but also whether the author has read them or asked a graduate student to compile them for the sake of academic appearances. Keith's footnotes are impeccable; you can learn a lot from them about the topic and you witness perfectionism at work. Describing Keith as "a historian's historian" is the highest compliment. James Joyce is a writers' writer; so is Marcel Proust. Dan Brown and John Grisham are not. Keith continued with several synthetic volumes on Romanian history: A Nation Discovered: Romanian Intellectuals in Transylvania and the Idea of Nation, 1700-1848 and A Nation Affirmed: The Romanian National Movement in Transylvania, 1860-1914 (The Encyclopedic Publishing House, Bucharest, 1999), The Identity of Romania (The Encyclopedic Publishing House, Bucharest, 2003), Ion Brătianu: Romania: The Peace Conferences of 1919-23 and Their Aftermath (Haus Publishing, 2011) and, above all, his long-awaited A Concise History of Romania (Cambridge University Press, 2014) which today is the standard introduction in undergraduate and gradiate courses alike. He also edited a number of important edited volumes, among them The Nationality Problem in Austria-Hungary: The Reports of Alexander Vaida to Archduke Franz Ferdinand's Chancellery (Brill, 1974) and with Miodrag Milin, Romanian-American Relations: Diplomatic and Consular Documents, 1859-1901 (Bucharest, 2001). In his hundreds of articles and encyclopedia entries, Keith Hitchins made important contributions to Hungarian, Bulgarian, Georgian, Azerbaijani, Kurdish, Tajik, and Arab history and literature. In his retirement, he continued to work on two projects-a history of Romanian communism and a history of southeastern Europe.

Keith served the profession selflessly as the long-time editor of Rumanian Studies, Studies in East European Social History, and of the Journal of Kurdish Studies. He was a consultant of the Council for International Exchange Scholars and of the Joint Committee on Eastern Europe of the American Council of Learned Societies and Social Science Research Council, and a member of numerous editorial boards, including the Slavic Review. Last, but not least, he authored hundreds of reviews in which he promoted the work of younger colleagues, continuing to write until the last year of his life. He was also one of the pillars who contributed to make the holdings of the former Slavic and East European Library and now collection at Illinois legendary. A tireless and dedicated teacher, Keith mentored generations of students, sharing his fabulous private collection of rare books that he assembled in the course of a lifetime, converting his modest home in Urbana into a virtual library. He possessed a quality that would always make him young: an unquenchable intellectual curiosity and thirst for new knowledge, coupled with an almost protestant work ethic. Even while he was fighting illness, he would get up at 4 am and walk to his office by 6 am waiting for Espresso Royal to open at $7 \mathrm{am}$. If you were an early riser and met Keith for coffee, he would have a grammar in his hand to refresh his Kurdish, Persian, or Georgian. His knowledge of languages was staggering. In his own modest and conservative estimation, his reading knowledge covered Romanian, French, German, Russian, Hungarian, Bulgarian, Italian, Spanish, Serbo-Croatian, Slovak, Modern Greek, Turkish, Kurdish, Tadjik, Persian, Kazakh, Uzbek, Azerbaijani, Georgian, and 
Arabic. Keith Hitchins was the recipient of several prominent awards for his scholarship and service. He received eight honorary degrees from different institutions in Romania: the universities of Bucharest, Cluj, Iaşi, Sibiu, Alba Iulia, Timişoara and Târgu Mureș, as well as from the Romanian Academy of Sciences. He was twice distinguished with the National Order of Merit from the President of Romania in 2000 and 2016. His exceptional contributions to the field were recognized by ASEEES in 2000, with its Distinguished Achievement Award.

There are so many wonderful sides of Keith Hitchins as scholar and teacher that it might seem redundant to speak about him as a human being. Yet, this is the first thing that people who knew and remember him emphasize: his modesty, given his vast erudition and major achievements, "the true embodiment of scholar and gentleman," his generosity, his sweet sense of humor, his disarming gentleness. One of his students remembered Keith reminiscing about a personal meeting with Nicolae Ceausescu while doing research in Bucharest. Keith was the epitome of a moral human being and was not shy of his liberal views but did not have an unkind or demeaning word to say about the dictator. His kindness was limitless.

Such qualities are very rare. They are among the qualities that his former students consistently credited him with: kindness, gentleness, supportiveness, and super-human erudition. One recalled how Keith very generously agreed to be on his dissertation committee after he arrived at UIUC when a previous member had dropped off. He recalled that Keith was exceedingly gracious and positive about everything he submitted, adding that Keith's comments to him at reading groups were unfailingly focused, considered, and interesting, even once when he accidentally ate cat food in front of a group of horrified participants. Another student recalls most intimately that he travelled to her wedding in Detroit. She remembers Keith as a generous teacher, mentor, and very dear friend, and how his kind support was crucial for her when she started working with him after first arriving in the US for graduate school after having grown up in Romania, where she was well-acquainted with Keith's written work. Another described how "everyone in our close-knit student cohort adored Prof. Hitchins. His modest house in Urbana was a temple of his boundless intellectual pursuits. Its double-shelved, climate-controlled, converted garage held the best Romanian library collection in the United States, and all rooms featured sections dedicated to all east European (and a few Central Asian) countries, with volumes in the original languages." Another former student related an exchange with Keith that captured the man: after expressing some uncertainty about the direction of his graduate study focusing on Bulgaria, he expressed interest in studying Mongolian in Ulaanbaatar over a summer. Keith was tremendously supportive. This led to a discussion of the possibility of acquiring some books about the Uighurs while in China. "The next day, I received a ten-page, closelytyped list of books that he hoped I might be able to find. Amazingly they were typed on a Chinese language typewriter!" "You speak Chinese?" I asked him. "I can get around." Another student described meeting Keith while on a research trip in Chișinău, Moldova, where he had been invited to speak to students of Moldova State University: "Keith gave the entire talk, including taking questions, in Romanian, which impressed the students greatly." Indeed, another student recalled this as a great source of inspiration: "Keith's expertise and the way he embraced learning new subjects and new languages and visiting new places no doubt inspired everyone whom he mentored." Many other former students focused on Keith's kind support for them. One wrote: "Some mentors are overpowering figures, whose students feel like they need to please, to live up to, to demonstrate their worth over and over. But that was not Keith.... he did not pressure his students into molds of his own scholarly vision. Instead, he provided the opportunity for everyone to flourish on 
their own terms." Another summed up: "Yet for all his achievements and honors, he was also modest, down-to-earth, and kind: a 'first-class gentleman' in the most genuine sense.” Keith will be fondly remembered and greatly missed.

MARIA TODOROVA
University of Illinois at Urbana-Champaign
DMITRY TARTAKOVSKY
University of Illinois at Urbana-Champaign

\section{David Shneer}

David Shneer (1972-2020) was a rule breaker, a field builder, an academic with unlimited imagination, a generous colleague and mentor, and above all, a remarkable human being. He authored, co-authored, edited, and co-edited eleven books. He created educational websites, curated exhibits, won book awards, designed the "Transforming the Archive Project" bringing together artists and historians, and coedited, with me, the journal East European Jewish Affairs. He was active, energetic, witty, creative, and unbelievably productive. Cancer tragically took his life much too early, but in the short time that he was here he made unparalleled impacts in scholarship, activism, mentorship (especially with younger colleagues), and fighting for the rights of women, queer, and transgender people.

I have known David Shneer for over twenty years, ever since he was a graduate student at Berkeley, and throughout his career as a Professor and Department Chair at the University of Colorado, Boulder, as well as co-editor of East European Jewish Affairs. Without hesitation, I can say that Shneer's work has been nothing short of revolutionary in how it approached important but difficult topics, how it presented the findings of this research, and how it affected both academic and lay audiences.

His books on Soviet Jewish history and culture, Yiddish and the Creation of Soviet Jewish Culture (Cambridge, 2004), Through Soviet Jewish Eyes: Photography, War, and the Holocaust (Rutgers, 2011), and most recently Grief: The Biography of a Holocaust Photograph (Oxford, 2020) broke new ground in how we understand the Soviet Jewish experience and the lives of intellectuals in the Soviet Union. Shneer told the story of these Soviet Yiddish intellectuals as dreamers, idealists, and romantics: as people who wholeheartedly believed that they could change the world with their work after the Russian Revolution. He himself was a romantic, too-believing in the power of imaginative scholarship to change old prejudices.

Shneer's other award-winning book, Through Soviet Jewish Eyes: Photography, War, and the Holocaust, made an even bigger impact. His main argument, which suggested that many photographers and operators who were embedded with the Red Army were Jewish, changed the way historians understood wartime footage, the mechanism of the Soviet mobilization, and above all, whether Jewish producers of Soviet culture managed to influence how Soviet people made sense of the war. Most scholars would end just there, especially after their book wins a national prize (2013 Jordan Schnitzer Book Award in the category of Jews and the Arts), but for Shneer, this was just the beginning. He worked with museum curators to organize exhibits of Soviet Jewish wartime photographers, which travelled across the United States and Europe. It exposed a large number of people to this important chapter in history, one which they would otherwise never have had access to. It transformed the way people understood the story of the Holocaust, and the role that Soviet Jews played in defeating it. 
His book New Jews (NYU, 2005), which he co-authored with Caryn Aviv, caused quite a stir in Jewish studies as it argued that Israel is losing its central place in making sense of Jewish diasporic identity. Today, it is on the syllabi of almost all courses on Jewish culture around the world.

Grief, Shneer's final book, came out a month before his passing. It focused on never published photographs of Nazi atrocities in the Soviet Union. It brought together stories of unthinkable violence, visual art, and oral testimonies in order to tell the history of the Holocaust through a lens that has always been important to Shneer: it needs to be seen as a human event.

His latest project, the one that he was working on when cancer cut his life short, focused on Lin Jaldati, a Dutch Yiddish singer who survived the war in Auschwitz and Bergen-Belsen, and was the last person to see Anne Frank alive. Contemporary Jewish studies professors, artists, musicians, and actors around the world often discuss new directions in their fields, about blurring the lines between scholarship and art, when instead of books, academics can produce music, theatrical performances, or a visual art exhibit.

I remember hosting Shneer and singer Jewlia Eisenberg at the University of Toronto. Together, they performed the story of Jaldati. The students in the audience did not feel the urge to revert to their devices to multi-task as the live performance was directly in front of them, presenting scholarship in new ways they could understand and appreciate. Both faculty and community members in the audience commented on how this was one of the best academic events that they had attended in years.

Editing the journal with David was an example of the perfect academic partnership-he saw the spark of discovery beyond stylistic issues, helped so many authors to crystallize their thoughts, and helped them shine. So many people got a jumpstart in their careers because their first article, edited and revised by David, appeared in our journal.

I cannot think of any other colleague in the field who excelled in pushing the boundaries of scholarship and genres of knowledge dissemination while reaching out to the broadest possible groups of people on the same level as David Shneer did. Even if he did only what is required or expected of a scholar-such as publishing university press books and articles, editing a journal, teaching undergraduate and graduate students, as well as chairing a department, he would have been a star. But he redefined how scholars understand academic work with each of his projects. I think that without David Shneer, the entire field of Russian Jewish studies, and history in general would have looked very different. His way of thinking, ability to find angles that revolutionized findings, and talent in developing new ways of demonstrating his results were unmatched. We will miss him every day.

ANNA SHTERNSHIS

University of Toronto

\section{Robert Bird}

It is with deep sadness and disbelief that we have faced the passing of our colleague Robert Bird on September 7, 2020. Robert was diagnosed with colon cancer at Christmas time, and in his characteristically stoic way, asked that his colleagues in the Slavic Department not be told until after the holidays. Though the cancer was at an advanced stage, we all believed that his remarkable physical and internal strength would sustain him to the farther limits of his prognosis. One of the first words you 
think of with Robert is "strong." He was physically strong, bicycling to work from Edgewater to Hyde Park, playing squash at the end of a long day of work-but he also had a powerful will, firm opinions, and a strong presence. It was hard to believe that he could be ill, and now it is hard to believe that he is gone.

Robert is going to be deeply missed by friends and colleagues from all over the world. His intellectual life was truly global in scope: in the spring he often taught at the University of Chicago Paris Center, which he also used as a base for projects and conferences with French colleagues; in summers he attended Russian and international film festivals and conducted research in Russian archives; and throughout the year he was constantly being invited to give talks at international conferences. But he was just as engaged at the local level, where he was known for his many collaborations. His efforts on this front were perhaps most evident in 2017, when he worked tirelessly in a series of projects marking the centennial of the Russian Revolution. In the fall off that year, visitors were flocking to the marvelous Revolution Every Day exhibit at the Smart Museum, which he curated with his wife Christina Kiaer and Zachary Cahill, and to the Red Press exhibit in Special Collections at Regenstein Library, which he had curated with me and a group of graduate students; we were all purchasing the remarkable catalogue for the Smart Exhibit, in the form of a Sovietstyle flip calendar filled with essays and primary documents, that he produced with Christina Kiaer and Zachary Cahill; in the meantime, he was co-teaching a coveted course on the Revolution with Sheila Fitzpatrick and a graduate seminar on the aesthetics of Socialist Realism with Christina Kiaer. Following this intensive effort, he continued his collaboration with filmmaker Cauleen Smith, whose work had been included in the Smart Museum exhibit, co-teaching a course with her and developing a project on Paul Robeson and the revolutionary potential of film. He also developed the Revolutionology project, involving three conferences over that year and next, including "1968 Decentered," which resulted in a special issue of South Atlantic Quarterly and his essay on punk music and philosophy. Last year he had received another round of funding for Revolutionology, and he paved the way for several additional conferences in that series.

These efforts were preceded by other memorable conferences he had organized, including "Scale Models: An Interdisciplinary Symposium" (2012), and "In the Long Shadow of Empire: Modern Constructions of Central Eurasia" (2016), which he organized with two graduate students. We were all the beneficiaries of his ambition and his generous commitments. He worked tirelessly with his students, both graduate and undergraduate, and could often be seen holding long sessions with them as he led them through independent studies and research projects. His letters of recommendation were written with painstaking dedication, and were full of the sort of salient details that one can only produce after sustained and close attention to a student's work. He followed and supported his former students with unbending fortitude, always giving them straight talk on their work and encouragement in their efforts to build their careers. The same could be said for his colleagues: I personally will always be grateful to him for the attention he devoted to my tenure case, and am going to miss his sound advice on topics both professional and personal.

The University community is going to feel his loss whenever a Russian film is shown at the Film Center, where he time and again gave audiences a compelling framework for interpreting and enjoying obscure and classic works of Russian and Soviet cinema. We will miss his sense of humor-always wry, sometimes slipping past unnoticed if you weren't paying attention. Years ago, a graduate student told me that hearing him read French poetry in a morning class was the highlight of their day. So many of us wanted more time with him, but we can be grateful for the time we had with him, when he gave us so much. 
Robert was born on September 16, 1969. He earned his BA from the University of Washington in 1991, majoring in Russian Language and Linguistics \& Russian Area Studies, and receiving honors for his thesis, "Swearwords and Prayers: Contemporary Russian Rock Poetry.” He completed his PhD in Slavic Languages and Literatures at Yale University in 1998, writing his dissertation on Viacheslav Ivanov. After teaching for three years at Dickinson College, in 2001 he was hired by the Department of Slavic Languages and Literatures at the University of Chicago. He also became a member of the Department of Cinema and Media Studies and the College, and was an associate member of the Divinity School. He served as chair of the Slavic Department, Cinema and Media Studies, and of the Fundamentals program. He published an astonishing amount of work across an extraordinary range of topics and approaches. His first book, The Russian Prospero: The Creative Universe of Viacheslav Ivanov, was followed by two books on Andrei Tarkovskii, including Andrei Tarkovsky: Elements of Cinema, which has been translated into Chinese, Farsi, and Portuguese, and will be published this year in Moscow in his own translation into Russian (Тарковский: Стихии кино). He also wrote a critical biography of Fedor Dostoevskii, and produced a volume of translated and annotated essays by Ivanov, and an anthology of Slavophile literature. He edited numerous volumes and journal issues in both Russian and English, and became a trusted authority in matters of translation, including most recently in a beautiful dual-language volume on Eisenstein's home. Just days before his death he completed work toward a volume of his collected essays in Russian, which will be published in Russia in the series Sovremennaia Rusistika. He was also completing a highly anticipated book, Soul Machine: How Soviet Film Modeled Socialism, which represents tremendous labor over many years, and will be published posthumously.

His breadth of interests and approaches is attested by the range of topics of his articles: from Russian iconography, to Martin Heidegger and Russian Symbolist Philosophy, to the Soviet obsession with peat and Medvedkin's Film Train. He was a scholar of the old school in terms of his philological rigor and philosophical depth, but he was at the same time deeply engaged in new models of scholarship, and was noted for his political engagement and concern for issues of gender and racial equality. He had recently been working more in the intersection of art, exhibition, and scholarship, in the hope of reaching new audiences through new forms. Characteristic of these later tendencies are his publications in e-flux ("Articulations of (Socialist) Realism: Lukács, Platonov, Shklovskii," "How to Keep Communism Aloft”), Art Agenda ("DAU," "On Museum Installations of Film Art”), The Point ("1989"), and Portable Gray ("Moscow Diary").

He also worked on himself, even in his illness-from his early resolve to make best of the situation and his commitment to fight for time, to his stoic reports on the relentless progression of the disease, even as his condition became increasingly grave. He contributed two beautiful essays on his illness, both exemplifying his pristine prose and measured reflection: "Illness in a plague year" (The Point, April 15), and "The Omens: Tarkovsky, Sacrifice, Cancer," which just appeared September 9, in Apparatus. He did not succumb to bitterness, but spoke of plans to spend time with his family, of his appreciation for his home, and of the rich variety of berries he was cultivating in his garden.

Eternal memory, dear Robert. You left so much behind for us, and will continue to be present with us in so many ways.

WILLIAM NICKELL University of Chicago 